\title{
A Markov-switching dynamic regression analysis of the asymmetries related to the determinants of US crude oil production between 1982 and 2019
}

\author{
Serge Djoudji Temkeng ${ }^{1}$. Achille Dargaud Fofack ${ }^{2}$
}

Received: 19 July 2020 / Accepted: 22 December 2020 / Published online: 29 January 2021

(c) The Author(s) 2021

\begin{abstract}
The structural changes brought about by shale oil revolution have inspired this paper of which the aim is to analyze the potential asymmetries related to the determinants of crude oil production in the USA. Thus, using a Markov-switching dynamic regression model in which parameters change when oil production moves from one regime to the other, it is found that for both oil production and oil relative importance, the regime that was dominant during the 1980s and the early 1990s when oil production in the USA was substantially high is the same regime that has once again become dominant in the decade corresponding to the shale oil revolution. Furthermore, the study reveals the existence of asymmetries in the relationship between US crude oil production and both manufacturing production and the consumer price index. Asymmetries are also found in the relationship between the relative importance US crude oil and manufacturing production. Finally, it is found that the intercept and the variance parameter also vary from one regime to the other, thus justifying the use of regime-dependent models.
\end{abstract}

Keywords Crude oil production $\cdot$ Energy markets $\cdot$ Regime switching

\section{Introduction}

Hydrocarbons are the primary energy source upon which contemporary civilizations are built. They affect almost every aspect of our daily lives from our homes to our schools, hospitals, transportation means, and industries (Trantin 2017). The importance of hydrocarbons is particularly relevant in the case of the USA, the world largest economy and leading oil consumer. Every year, companies dealing in oil generate millions of high-paying jobs and spend substantial amounts in tax revenues at local, state, and federal levels (NPC 2011).

Historically, US crude oil production decreased steady in the last three decades before the Great Recession, with the

Edited by Xiu-Qiu Peng

Achille Dargaud Fofack

achille.fofack@rdu.edu.tr; adfofack.irlaem@gmail.com

1 Department of Economics, University of Buea, Buea, Cameroon

2 Department of Business and Economics, Rauf Denktaş University, Lefkoşa, Turkey production index for crude oil moving from 148.95 in August 1972 to 76.64 in September 2007 as depicted in Fig. 1. The steady fall in oil production associated with a rising domestic demand led the USA to become a net oil importer. The vulnerability inherent to such a position became obvious in 1973 when the Organization of Arab Petroleum Exporting Countries imposed an oil embargo and threatened US energy security. The country responded with the Energy Policy and Conservation Act of 1975 which banned oil export (Brown et al. 2014) and ultimately reshaped its foreign policy to support its energy security.

The decades preceding the Great Recession also saw a surge in oil prices as the spot price for the West Texas Intermediate (WTI) — a US benchmark-rose from $\$ 3.56$ per barrel in August 1972 to $\$ 79.93$ per barrel in September 2007. Associated with technological progress in horizontal drilling and hydraulic fracturing, this surge in oil prices made it economically viable to extract the oil trapped in rock formations of low permeability and led to what is known today as the shale oil revolution (Trantin 2017; Alvarez and Di Nino 2017).

The shale oil revolution brought about structural changes in US crude oil production and overall energy security. 


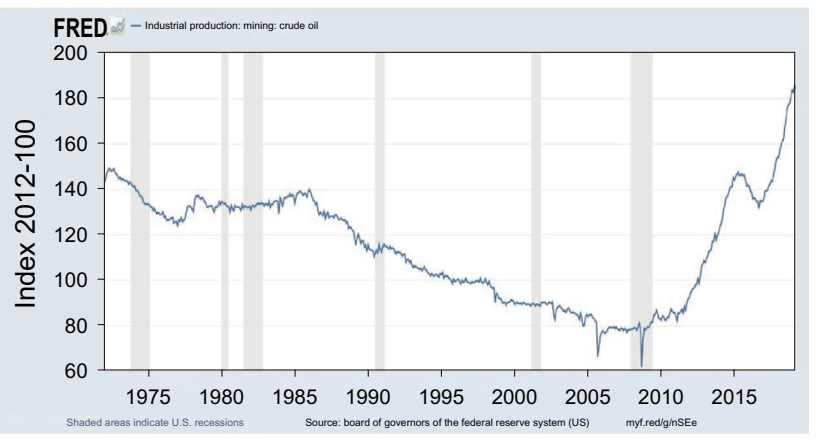

Fig. 1 US crude oil production. Source: Federal Reserve Economic Data (FRED)

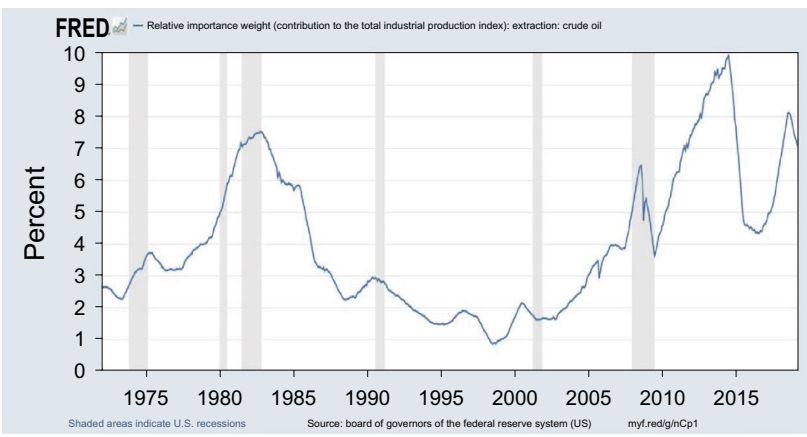

Fig. 2 Relative contribution of crude oil production to US industrial production index. Source: FRED

The production of shale oil increased almost tenfold from 250,000 barrels per day in 2000 to 2.25 million barrels per day in 2012 (Brown et al. 2014), driving an upward trend in US oil production (EIA 2019a). Thus, the production index for crude oil is more than doubled between September 2007 and February 2019, moving from 76.64 to 185.36 . Furthermore, as depicted in Fig. 2, the contribution of crude oil production to the industrial production index has recently risen to unprecedented levels, hitting the $10 \%$ mark in June 2014. The previous peak was reached in November 1982 when crude oil accounted for $7.50 \%$ of the industrial production index.

Driven by the shale oil revolution, US oil production has risen to historically high levels and the country has become the world leading oil producer. Thus, the three main shale oil wells-Bone Spring, Spraberry and Wolfcamp-located in the Permian Basin accounted for $41 \%$ of US oil production in 2018 and drove total US oil production to about 10.96 million barrels per day (EIA 2019a, c). Furthermore, the US Energy Information Agency (EIA) has been revising upward the projections related to shale oil production and overall US oil reserves (Alvarez and Di Nino 2017; EIA 2019f). At the end of 2017, the proved reserves of crude oil in the
USA increased $19.5 \%$ to 39.2 billion barrels, surpassing the former record of 39 billion barrels set in 1972 (EIA 2018).

The mismatch between the physical and chemical properties-high API gravity (light) and low sulfur (sweet)of the abundant oil brought about by the shale revolution and the heavy oil traditionally processed by US refineries, led US authorities to lift the ban on crude oil exports on December 18, 2015 (Brown et al. 2014; Humphries 2016). Thus, the US exported 1.2 million and 2.0 million barrels per day in 2017 and 2018, respectively. In 2018, the primary destinations of these exports were Canada $(378,000$ barrels per day), South Korea (236,000 barrels per day), and China (228,000 barrels per day) (EIA 2019d). The American Petroleum Institute (2016) estimates that US exports of crude oil could generate up to 300,000 jobs and lead to an increase of $\$ 38.1$ billion in US gross domestic product in 2020. As for US refineries, they are progressively backing out of oil imports and increasing their consumption of shale oil. Thus, the gross input of those refineries hit five consecutive annual record high between 2014 and 2018. In 2018, the average gross input reached 17.3 million barrels per day (AFPM 2015; EIA 2019b).

The structural changes brought about by the shale oil revolution also affect financial markets. On the one hand, the return on equity made by US crude oil producers hit a record high $\$ 28$ billion in 2018. To put this into perspective, one should note that the previous record goes back to 2013 when oil prices were 40\% higher (EIA 2019e). On the other hand, as reveal by the US Commodity Futures Trading Commission (2018), the shale boom has led to a significant fall in NYMEX WTI contracts for delivery five or more years. Indeed, the short lifespan of tight oil wells has reduced the need to hedge production beyond 3 years. Thus, open interest for NYMEX WTI contracts for delivery five or more years dropped from 46,158 contracts (46.2 million barrels) in 2008 to 481 contracts (481,000 barrels) in March 2018.

In the wake of all the structural changes brought about by the shale oil revolution, one could logically ask whether the relationship between US crude oil production and its determinants has not been altered. Thus, using a Markovswitching dynamic regression model in which parameters change when oil production moves from one regime to the other, this paper aims at analyzing the potential asymmetries related to the determinants of crude oil production in the USA over the period from January 1982 to February 2019. To the best of our knowledge, this is the first study analyzing the shale oil boom with regime-dependent models. Robustness check is done with different proxies of oil production, namely the crude oil production index and the relative contribution of crude oil production to the industrial production index. The remainder of the paper is organized as follows: Sect. 2 presents the methodology; the main findings and the 
Table 1 Description of the variables

\begin{tabular}{ll}
\hline Name & Definition \\
\hline Oil & Crude oil production index; base year=2012; seasonally adjusted \\
Importance & $\begin{array}{c}\text { Relative contribution (in percentage) of crude oil production to US industrial production index; } \\
\text { seasonally adjusted } \\
\text { Manufacturing }\end{array}$ \\
MPI & Consumer price index for all urban consumers: all items; base year =1982-1984; seasonally adjusted \\
WTI & Global price of WTI crude oil in dollars per barrel \\
Spread & 10-year treasury rate minus 3-month treasury rate \\
Recession & Dummy variable equal to 1 during recessions and 0 elsewhere \\
\hline
\end{tabular}

related discussion are contained in Sects. 3 and 4 concludes the paper.

\section{Methodology}

\subsection{Data}

The monthly data obtained from the FRED cover the period from January 1982 to February 2019. The dependent variable-US crude oil production-is proxied by crude oil production index, and as reported in Table 1, five independent variables are included in the analysis. The manufacturing production index and the consumer price index (CPI), respectively, account for domestic activity and price level. On the one hand, it is assumed that an increase in the manufacturing production index induces an increase in the demand for crude oil and ultimately leads to an increase in domestic oil production. On the other hand, an increase in the CPI is expected to induce a fall in the real value of the dollar, depress the buying power of Americans as well as their demand for oil, and finally lead to a fall in domestic oil production.

The term spread-difference between the 10-year and the 3-month treasury rates-accounts for the financial health of the US economy as a narrow spread reflects the optimism of economic agents about the ability of the federal government to meet its financial commitments in the future. As for the global price of WTI crude, it accounts for the global demand for US oil and it is assumed that an increase in this indicator reflects an increase in the global demand for US oil and ultimately leads to an increase in US oil production. Finally, a dummy variable is included in the analysis to account for US recessions as it is assumed that economic turmoil alters
Robustness check is done using the relative contribution of crude oil production to US industrial production index as dependent variable. The aim here is to examine whether the potential asymmetric patterns affecting crude oil production are also affecting the relative weight of crude oil in the American economy.

\subsection{Markov-switching model}

Switching regressions are models allowing the estimated parameters to change depending on the realization of one among many unobservable states. This approach developed by Golfeld and Quandt (1973) is now commonly used for the estimation of asymmetries in economic patterns (SimoKengne et al. 2013). In this paper, it is assumed that throughout period from January 1982 to February 2019, US crude oil production switches between two unobservable states: bull market corresponding to high oil production and bear market corresponding to low oil production. Moreover, it is also assumed that the transition from one state to the other follows a Markov process ${ }^{1}$, but the time of transition as well as the duration in each state is random. Finally, the dynamic nature of the model comes from the assumption that adjustments are made quickly after a change of state.

The following model is used in the analysis:

$O i l_{t}=c_{s}+X_{t} \alpha+Z_{t} \beta_{s}+\epsilon_{s t}$

where $t$ accounts for time (month) and $s$ represents the unobserved states $(s=1,2) . C_{s}$ is a state-dependent intercept, $X_{t}$ is a matrix of state-invariant variables, $Z_{t}$ is a matrix of state-dependent variables, and $\in_{s t} \sim \operatorname{iidN}\left(0, \sigma_{s}^{2}\right)$ is the error term. The model also can be written as follows:

Oil $_{t}= \begin{cases}c_{1}+\alpha \operatorname{Recession}_{t}+\beta_{11} \mathrm{Manu}_{t}+\beta_{21} C P I_{t}+\beta_{31} \operatorname{Spread}_{t}+\beta_{41} \mathrm{WTI}_{t}+\epsilon_{1 t} & \text { if } s=1 \\ c_{2}+\alpha \operatorname{Recession}_{t}+\beta_{12} \mathrm{Manu}_{t}+\beta_{22} C P I_{t}+\beta_{32} \operatorname{Spread}_{t}+\beta_{42} \mathrm{WTI}_{t}+\epsilon_{2 t} & \text { if } s=2\end{cases}$

the behavior pattern of economic agents and induces a fall in both the demand for oil and the production of crude oil.
${ }^{1}$ A Markov process can be defined as a random process in which each future event depends only on the current event and not on any other past event. 
Table 2 Correlation matrix

\begin{tabular}{|c|c|c|c|c|c|c|}
\hline & CPI & Oil & Importance & Manufacturing & Spread & WTI \\
\hline CPI & 1 & & & & & \\
\hline Oil & $-1.121 * *$ & 1 & & & & \\
\hline Importance & $0.389 * *$ & $0.429 * *$ & 1 & & & \\
\hline Manufacturing & $0.937 * *$ & $-0.324 * *$ & $0.199 * *$ & 1 & & \\
\hline Spread & -0.045 & 0.030 & $0.162 * *$ & $-0.188 * *$ & 1 & \\
\hline WTI & $0.732 * *$ & $-0.148 * *$ & $0.736 * *$ & $0.649 * *$ & $0.094 * *$ & 1 \\
\hline
\end{tabular}

**Denotes significance at the 5 percent level

The conditional transition probability to switch from regime $i$ in the current month to regime $j$ in the next month is given by the following equation:

$\operatorname{Pr}\left(s_{t+1}=j \mid s_{t}=i\right)=P_{i j}$.

Thus, the two-state model used in this paper will lead to the following probability matrix:

$\left[\begin{array}{ll}P_{11} & P_{12} \\ P_{21} & P_{22}\end{array}\right]$

with $P_{11}+P_{12}=1$ and $P_{21}+P_{22}=1$

\section{Results}

The correlation coefficients between the variables used are reported in Table 2. On the one hand, those correlation coefficients reveal that crude oil production is negatively and significantly associated with inflation (CPI), the price of WTI crude, and manufacturing production. On the other hand, the table reveals that the relative importance of oil production is positively and significantly associated with crude oil production, inflation, the term spread, the price of WTI crude, and manufacturing production. Paying less attention to the overall dynamics of oil production in the USA and more attention to its regime-dependent dynamics, the stationarity of the series was tested before carrying out the regime switching analysis.

Globally, the augmented Dickey-Fuller, the Phillips-Perron, and the $\mathrm{Ng}$-Perron unit root tests reported in Table 3 reveal that the series are not stationary at level. Those unit root tests also reveal that the variables are stationary at first difference; consequently, the switching regression analysis is done with variables at first difference. The expected maximization estimation of the model is done with 2 states and the initial unconditional probabilities set to transition. An intercept is added to the model, and it is allowed to vary across states together with the variance parameter.

As depicted in Fig. 3, the transition probability of state 2 reveals that this regime was dominant during the 1980s and the early 1990s when US crude oil production was substantially high (bull regime). The figure also reveals that this regime has once again become dominant in the decade corresponding to the shale oil revolution. This is in line with the assumed structural changes brought about by shale oil (Grubert 2018; Ulrich-Schad et al. 2020).

The results of the regime-switching regression reported in Table 4 reveal that economic recession is positively and significantly correlated with US crude oil production. Such a finding seems counterintuitive, but a close look at US data could justify it. Indeed, the US economy experienced 4 recessions during the period under review-January 1982 to February 2019-and crude oil production increased during all those recessions.

The crude oil production index moved from 131.49 in the beginning of the first recession (July 1981) to 133.61 when the economy came out of it in November 1982. Similarly, the index also moved from 111.92 in July 1990 to 114.82 in March 1991; from 89.30 in March 2001 to 90.14 in November 2001, and from 78.09 in December to 81.17 in 2009. Ultimately, it could be argued that recessions lead American agents to reduce oil imports and rely more upon domestic oil production. In the same vein, Solarin (2020) finds that shale oil production did increase during the Great Recession and helped support economic recovery in the USA.

State 1 parameter estimates show that none of the selected determinants has a significant impact on US crude oil production. It is found that manufacturing production and the term spread, respectively, have a positive and a negative impact on oil production as expected. As for the price of WTI crude, it is found to have a negative impact on oil production. It could be argued that a surge in the price of WTI crude leads to an insignificant depletion of the demand for oil and a corresponding insignificant fall in production. Finally, it is found that the CPI is positively associated with oil production. 
Table 3 Unit root tests

\begin{tabular}{|c|c|c|c|c|c|c|}
\hline \multirow[t]{2}{*}{ Variables } & \multicolumn{2}{|l|}{$\mathrm{ADF}$} & \multicolumn{2}{|l|}{ PP } & \multicolumn{2}{|l|}{$\mathrm{Ng}$-Perron } \\
\hline & I & TI & I & TI & I & $\mathrm{TI}$ \\
\hline \multicolumn{7}{|l|}{ Level } \\
\hline CPI & -0.246 & -2.672 & -0.187 & -2.455 & 1.552 & -13.011 \\
\hline Oil & 2.152 & 3.541 & 1.271 & 2.871 & -1.365 & -0.351 \\
\hline Importance & -1.945 & -2.623 & -1.560 & -2.249 & -2.523 & -3.420 \\
\hline Manufacturing & -1.627 & -1.920 & -1.382 & -1.567 & 0.805 & -7.579 \\
\hline Spread & -3.340 & -3.380 & $-3.092 * *$ & -3.109 & $-22.304 * *$ & $-22.164 * *$ \\
\hline WTI & -2.271 & -3.327 & -1.505 & -2.609 & $-9.838 * *$ & $-15.274 * *$ \\
\hline \multicolumn{7}{|l|}{ First difference } \\
\hline CPI & $-13.790 * *$ & $-13.775^{* *}$ & $-12.579 * *$ & $-12.561 * *$ & $-267.865^{* *}$ & $-271.136^{* *}$ \\
\hline Oil & $-4.557 * *$ & $-24.463 * *$ & $-23.817 * *$ & $-24.187 * *$ & -2.609 & -3.537 \\
\hline Importance & $-6.260^{* *}$ & $-6.375^{* *}$ & $-14.831^{* *}$ & $-14.922 * *$ & $-56.175^{* *}$ & $-62.847 * *$ \\
\hline Manufacturing & $-5.783 * *$ & $-5.868 * *$ & $-19.885^{* *}$ & $-19.882 * *$ & -6.533 & $-18.883^{* *}$ \\
\hline Spread & $-14.710^{* *}$ & $-14.712 * *$ & $-15.842 * *$ & $-15.850 * *$ & -0.012 & -1.336 \\
\hline WTI & $-14.052 * *$ & $-14.037 * *$ & $-13.696 * *$ & $-13.679 * *$ & $-185.039 * *$ & $-187.581 * *$ \\
\hline
\end{tabular}

**Denotes significance at the 5 percent level; I stands for intercept and IT stands for trend and intercept
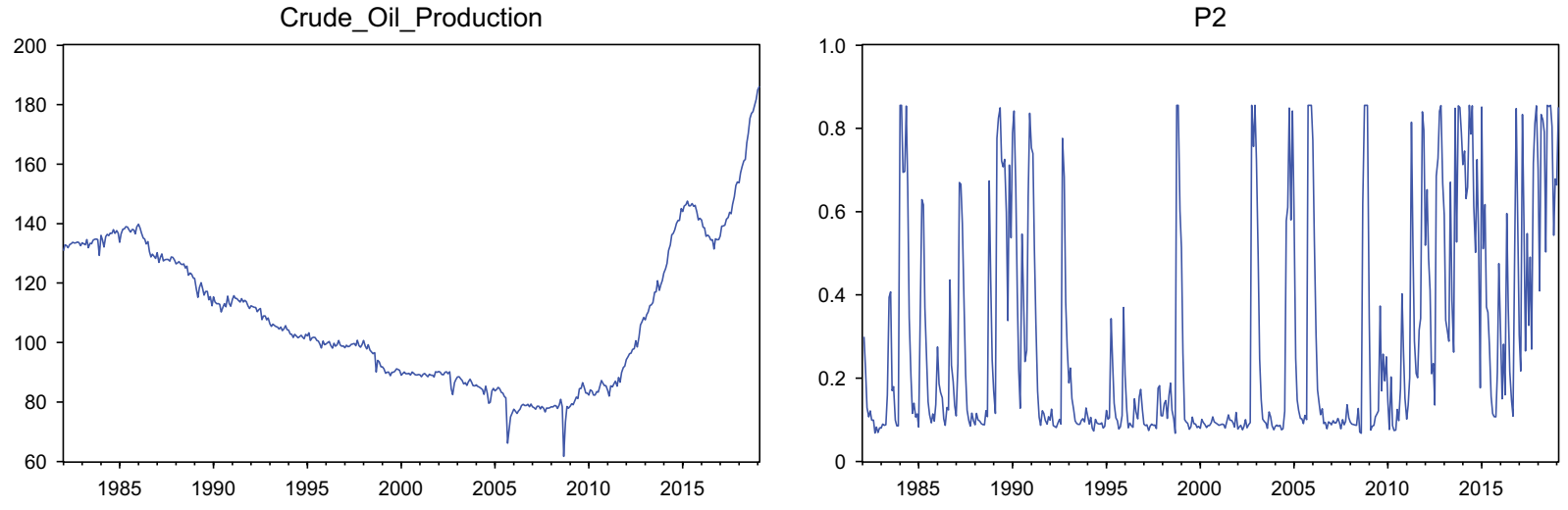

Fig. 3 Transition probability of state 2 in the case of crude oil production

State 2 parameter estimates show that manufacturing production and the CPI have a significant impact on crude oil production. As expected, manufacturing production has positive and significant on crude oil production, while the CPI has a negative impact. Furthermore, the price of WTI crude and the term spread are found to have a positive but insignificant impact on oil production. The insignificant effect of WTI oil prices is in line with Monge et al. (2017) who analyzed the relation between US shale oil production and WTI oil price behavior. They reveal that the correlation between those variables is not stable over time as they find it to be positive during the 2003-2009 period and a negative during the 2009-2014 period. As for the unexpected positive impact of the term spread, it could be due to the distortions created by quantitative easing $(\mathrm{QE})$ as the $\mathrm{QE}$ programs implemented by the US Federal Reserve aim at artificially compress the term spread and could have altered the effect it has on the real economy.

Paying attention to the properties of the two regimes, Table 5 shows that the transition probability from one regime to the other is quite low. The probability to switch from regime 1 to regime 2 is 0.061 while the probability to switch from regime 2 to regime 1 is 0.144 . As for the duration of each regime, the table shows that on average, regime 1 lasts longer (16 months) than regime 2 (7 months). Finally, testing the equality of coefficients across regimes, Table 6 shows that manufacturing production, the CPI, the intercept, and the variance parameter are significantly different across 
Table 4 Estimation results for crude oil production

\begin{tabular}{lll}
\hline & Coefficient & Standard error \\
\hline $\begin{array}{l}\text { State-invariant parameter } \\
\text { Recession }\end{array}$ & $0.765^{* * *}$ & 0.254 \\
State 1 parameter estimates & & \\
WTI & -0.024 & 0.027 \\
Manufacturing & 0.209 & 0.135 \\
Spread & -0.316 & 0.217 \\
CPI & 0.334 & 0.206 \\
Intercept & $-0.284^{* * *}$ & 0.106 \\
Sigma & 1.016 & 0.082 \\
State 2 parameter estimates & & \\
WTI & 0.023 & 0.063 \\
Manufacturing & $2.318^{* * *}$ & 0.489 \\
Spread & 2.675 & 1.671 \\
CPI & $-2.020^{* * *}$ & 0.560 \\
Intercept & $1.125^{* * *}$ & 0.369 \\
Sigma & 2.835 & 0.207 \\
Observations & 446 & \\
AIC & 3.802 & \\
HQIC & 3.856 & \\
SBIC & 3.940 & \\
Log likelihood & -831.037 & \\
\hline
\end{tabular}

**Denotes significance at the $5 \%$ level; *** denotes significance at the $1 \%$ level

regimes. It can therefore be concluded that there are asymmetries in the relationship between US crude oil production and those two determinants. Further, these asymmetries support the use of regime-dependent models in this paper.

For robustness check, the regime-switching model is now estimated with the relative contribution of crude oil production to US industrial production index as dependent variable and the transition probability of state 1 is depicted in Fig. 4. The figure shows that this regime was dominant during the 1980s and the early 1990s when US crude oil importance was substantially high (bull regime) and that it has once again become dominant in the decade corresponding to the shale oil revolution. This supports what was found in the case of oil production; that is, bull regime is dominant when US crude oil production/importance is high and bear regime is dominant when it is low.

The estimation results reported in Table 7 show that recession is negatively and insignificantly associated with crude oil importance. The sign of this relationship is in line with expectations as recession induces a fall in economic activity and demand for energy. Paying attention to state 1 parameter estimates, the results show that manufacturing production and the price of WTI crude oil both have a positive and significant impact on the importance of crude oil. This is also in line with economic theory as a boom in
Table 5 Regime properties for crude oil production

\begin{tabular}{lll}
\hline & Coefficient & Standard error \\
\hline Transition probabilities & & \\
$\mathrm{P}_{11}$ & 0.938 & 0.025 \\
$\mathrm{P}_{12}$ & 0.061 & 0.025 \\
$\mathrm{P}_{21}$ & 0.144 & 0.063 \\
$\mathrm{P}_{22}$ & 0.855 & 0.063 \\
Duration & & \\
State 1 & 16.195 & 6.764 \\
State 2 & 6.924 & 3.039 \\
\hline
\end{tabular}

Table 6 Test on the equality of coefficients across regimes

\begin{tabular}{ll}
\hline Variable & Chi square \\
\hline WTI & 0.42 \\
Manufacturing & $16.90^{* *}$ \\
Spread & 3.01 \\
CPI & $14.71 * *$ \\
Intercept & $13.33 * *$ \\
Sigma & $105.73 * *$ \\
\hline
\end{tabular}

**Denotes significance at the $5 \%$ level

either determinant creates more revenue for the petroleum sector. As for the CPI and the term spread, their impact on the importance of crude oil is found to be insignificant.

Looking at state 2 parameter estimates, the results show that the impact of manufacturing production and the price of WTI crude oil are still significant even though manufacturing production is now negatively correlated with the importance of crude oil. Regime 2 being the state in which the importance of US crude oil is low (bear regime), it could be argued that in such a regime, an increase in manufacturing production induces a surge in the demand for oil that cannot be met by domestic supply. Thus, manufacturers resort to oil imports and ultimately deplete the importance of domestic oil.

Table 8 reporting the properties of the two regimes shows that the probability to switch from one regime to the other is yet again low. The probability to switch from regime 1 to regime 2 is 0.038 while the probability to switch from regime 2 to regime 1 is 0.022 . As for the duration of each regime, the table shows that on average, regime 2 lasts longer (26 months) than regime 1 (45 months). Finally, testing the equality of coefficients across regimes, Table 9 shows that manufacturing production and the variance parameter are significantly different across regimes. Thus, it can be concluded that there are asymmetries in the relationship between the importance of US crude oil and manufacturing production across bull and bear regimes. Further, these asymmetries support the use of regime-dependent models in this paper. 

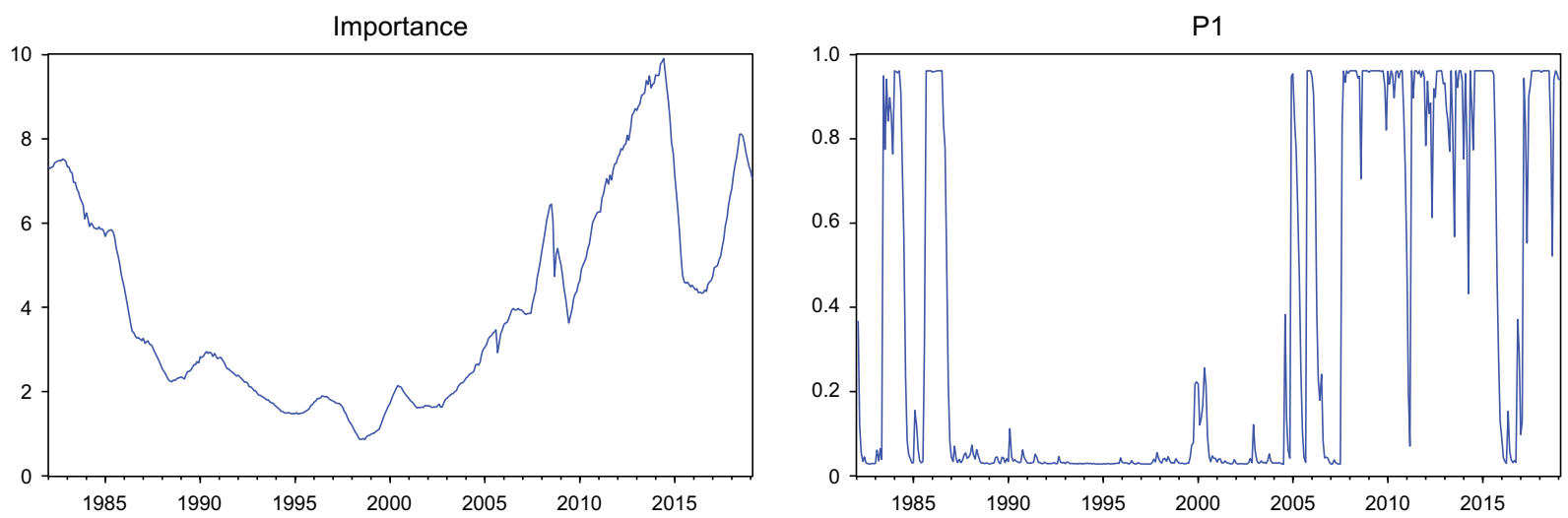

Fig. 4 Transition probability of state 1 in the case of crude oil importance

Table 7 Estimation results for crude oil importance

\begin{tabular}{lll}
\hline & Coefficient & Standard error \\
\hline State-invariant parameter & & \\
Recession & -0.016 & 0.012 \\
State 1 parameter estimates & & \\
WTI & $0.009^{* *}$ & 0.003 \\
Manufacturing & $0.081^{* * *}$ & 0.024 \\
Spread & 0.001 & 0.084 \\
CPI & -0.045 & 0.034 \\
Intercept & 0.014 & 0.021 \\
Sigma & 0.227 & 0.013 \\
State 2 parameter estimates & & \\
WTI & $0.003^{* *}$ & 0.001 \\
Manufacturing & $-0.014^{* *}$ & 0.007 \\
Spread & 0.002 & 0.010 \\
CPI & 0.018 & 0.011 \\
Intercept & -0.005 & 0.005 \\
Sigma & 0.049 & 0.002 \\
Observations & 446 & \\
AIC & -1.825 & \\
HQIC & -1.770 & \\
SBIC & -1.687 & \\
Log likelihood & 421.097 & \\
\hline & & \\
& &
\end{tabular}

$* *$ Denotes significance at the $5 \%$ level; $* * *$ denotes significance at the $1 \%$ level

\section{Conclusion}

In line with the structural changes brought about by shale oil (Grubert 2018; Solarin 2020; Ulrich-Schad et al. 2020), the results for both crude oil production and crude oil relative importance show that the (bull) regime that was dominant
Table 8 Regime properties for crude oil importance

\begin{tabular}{lll}
\hline & Coefficient & Standard error \\
\hline Transition probabilities & & \\
$\mathrm{P}_{11}$ & 0.961 & 0.016 \\
$\mathrm{P}_{12}$ & 0.038 & 0.016 \\
$\mathrm{P}_{21}$ & 0.022 & 0.009 \\
$\mathrm{P}_{22}$ & 0.977 & 0.009 \\
Duration & & \\
State 1 & 26.199 & 11.456 \\
State 2 & 44.946 & 18.890 \\
\hline
\end{tabular}

during the 1980s and the early 1990s when US crude oil production was substantially high is the same regime that has once again become dominant in the decade corresponding to the shale oil revolution. Paying attention to the state corresponding to the shale revolution, it is found on the one hand that manufacturing production and the CPI are significant determinants of US crude oil production. On the other hand, it is found that manufacturing production and the price of WTI crude are significant determinants of oil importance.

The results also reveal that in the case of crude oil production, the CPI and the variance parameter are significantly different across regimes. Thus, it can be concluded that there are asymmetries in the relationship between US crude oil production and those determinants. Furthermore, in the case of crude oil importance, it is found that manufacturing production and the variance parameter are significantly different across regimes. It can therefore be concluded that there are asymmetries in the relationship between the importance of US crude oil and manufacturing production. All the abovementioned asymmetries support the use of regime-dependent models and add to the innovation of this paper. 
Table 9 Test on the equality of coefficients across regimes

\begin{tabular}{ll}
\hline Variable & Chi square \\
\hline WTI & 1.68 \\
Manufacturing & $14.54^{* *}$ \\
Spread & 0.01 \\
CPI & 3.06 \\
Intercept & 0.75 \\
Sigma & $445.13^{* *}$ \\
\hline
\end{tabular}

**Denotes significance at the $5 \%$ level

Open Access This article is licensed under a Creative Commons Attribution 4.0 International License, which permits use, sharing, adaptation, distribution and reproduction in any medium or format, as long as you give appropriate credit to the original author(s) and the source, provide a link to the Creative Commons licence, and indicate if changes were made. The images or other third party material in this article are included in the article's Creative Commons licence, unless indicated otherwise in a credit line to the material. If material is not included in the article's Creative Commons licence and your intended use is not permitted by statutory regulation or exceeds the permitted use, you will need to obtain permission directly from the copyright holder. To view a copy of this licence, visit http://creativecommons.org/licenses/by/4.0/.

\section{References}

Alvarez I, Di Nino V. The oil market in the age of shale oil. ECB Econ Bul. 2017;8:57-74.

American Fuel \& Petrochemical Manufacturers. Refining U.S. petroleum, a survey of U.S. refinery use of growing U.S. crude oil production. 2015. https://www.afpm.org/uploadedFiles/RefiningUS-Capacity.pdf. Accessed 15 March 2019.

American Petroleum Institute. U.S. crude oil exports: benefits for America's economy and consumers. 2016. https://www.api.org/ / media/Files/Policy/Exports/Crude-Oil-Exports-primer/US-Crude -Oil-Exports-high-res.pdf. Accessed 15 March 2019.

Brown P, Pirog R, Vann A, Fergusson I, Ratner M, Ramseur J. U.S. crude oil export policy: background and considerations. Congressional Research Service 7-5700. 2014. https://www.energy.senat e.gov/public/index.cfm/files/serve?File_id=dfe108c9-cef6-43d09f01-dc16e6ded6b4. Accessed 15 March 2019.

EIA. Annual energy outlook 2019 with projections to 2050. 2019f. https://www.eia.gov/outlooks/aeo/pdf/aeo2019.pdf. Accessed 15 March 2019.

EIA. Despite crude oil price declines in the fourth quarter, 2018 was the most profitable year for U.S. oil producers since 2013. 2019e. https://www.eia.gov/petroleum/weekly/archive/2019/190417/inclu des/analysis_print.php. Accessed 20 April 2019.
EIA. The U.S. exported 2 million barrels per day of crude oil in 2018 to 42 destinations. 2019d. https://www.eia.gov/todayinenergy/detai 1.php?id=39072. Accessed 20 April 2019.

EIA. Tight oil development will continue to drive future U.S. crude oil production. 2019a. https://www.eia.gov/todayinenergy/detai 1.php?id=38852. Accessed 20 April 2019.

EIA. U.S. Crude oil and natural gas proved reserves, Year-End 2017. 2018. https://www.eia.gov/naturalgas/crudeoilreserves/pdf/usres erves.pdf. Accessed 15 March 2019.

EIA. U.S. crude oil production grew $17 \%$ in 2018 , surpassing the previous record in 1970. 2019c. https://www.eia.gov/todayinenergy/ detail.php?id=38992. Accessed 20 April 2019.

EIA. U.S. refinery runs hit fifth consecutive annual record high in 2018. 2019b. https://www.eia.gov/todayinenergy/detail.php?id=38913. Accessed 20 April 2019.

Golfeld S, Quandt R. A Markov model for switching regressions. J Econ. 1973;1:3-16. https://doi.org/10.1016/0304-4076(73)90002 -X.

Grubert E. The Eagle Ford and Bakken shale regions of the United States: a comparative case study. Extr Ind Soc. 2018. https://doi. org/10.1016/j.exis.2018.09.011.

Humphries M. U.S. crude oil and natural gas production in federal and nonfederal areas. Congressional Research Service 7-5700. 2016. https://fas.org/sgp/crs/misc/R42432.pdf. Accessed 15 March 2019.

Monge M, Gil-Alana L, Perez de Gracia F. U.S. shale oil production and WTI prices behaviour. Energy. 2017. https://doi. org/10.1016/j.energy.2017.09.055.

National Petroleum Council. Prudent Development, Realizing the potential of North America's abundant natural gas and oil resources. A report of the Committee on Resource Development. 2011. https://www.npc.org/NARD-ExecSummVol.pdf. Accessed 15 March 2019.

Simo-Kengne B, Balcilar M, Gupta R, Reid M, Aye G. Is the relationship between monetary policy and house prices asymmetric across bull and bear markets in South Africa? Evidence from a Markov-switching vector autoregressive model. Econ Model. 2013;32:161-71. https://doi.org/10.1016/j.econmod.2013.02.006.

Solarin S. The effects of shale oil production, capital and labour on economic growth in the United States: a maximum likelihood analysis of the resource curse hypothesis. Resour Policy. 2020;68:1-11. https://doi.org/10.1016/j.resourpol.2020.101799.

Trantin J. Crude oil prices spur gains for U.S. import and export price indexes, despite the appreciating dollar: 2016 annual summary. Monthly Labor Review. U.S. Bureau of Labor Statistics. 2017

U.S. Commodity Futures Trading Commission. Impact of U.S. tight oil on NYMEX WTI futures. Market Intelligence Branch, Division of Market Oversight. 2018. https://www.cftc.gov/sites/defau 1t/files/2018-09/DMO_TightOilImpactNYMEX_WTI0818.pdf. Accessed 15 March 2019.

Ulrich-Schad J, Larson E, Fernando F, Abulbasher A. The Golddilocks view: support and skepticism of the impacts and pace of unconventional oil and gas development in the Bakken shale of the United States. Energy Res Soc Sci. 2020;70:1-11. https://doi. org/10.1016/j.erss.2020.101799. 